\title{
Evaluation of the efficiency of an infection control protocol in dental radiology by means of microbiological analysis
}

\section{Avaliação da eficiência de um protocolo de controle de infecção em radiologia odontológica, por análise microbiológica}

Marcos André dos Santos da SILVA

Post-graduated student - Post-Program in Oral Biopathology - Area Dental Radiology - Dental School of São José dos Campos - UNESP - Brazil.

\section{Márcia Valéria MARTINS}

Specialist in Dental Radiology - EAP-ABO -Minas Gerais-Brazil and Post-graduated student - Post-Program in Oral Biopathology- Area Dental Radiology- Dental School of São José dos Campos - UNESP- Brazil.

\section{Edmundo MEDICI FILHO}

Luiz César de MORAES

Chairman Professor Discipline of Dental Radiology- Surgery, Periodontology and Radiology Dental DepartmentDental School of São José dos Campos - UNESP- Brazil.

\section{Julio Cezar de Melo CASTILHO}

Associate PhD Professor of the Discipline of Dental Radiology- Surgery, Periodontology and Radiology Dental Department- Dental School of São José dos Campos - UNESP- Brazil.

\section{Antonio Olavo Cardoso JORGE}

Chairman Professor of the Discipline of Microbiology and Immunology-Oral Biopathology Department— Dental School of São José dos Campos - UNESP- Brazil.

\begin{abstract}
The aim of this study was to verify the efficiency of an infection control protocol in dental radiology during radiographic exposure and processing, since the prevention of infectious diseases should be a matter of concern of the professional in all procedures. The areas selected for material collection were the film, tube head, dental chair, lead apron, buttons, protective barrier, darkroom bench and processing solutions (developer solution, water and fixer solution). Material was collected from each area both before and after establishment of the infection control protocol. Ten RODAC plates were employed for each site, adding up to 140 plates ( 70 before and 70 after), besides 60 Petri plates (30 before and 30 after) containing blood agar as the culture medium. The processing solutions were dropped on the Petri plates, whereas the material collected from the other areas was directly collected on the RODAC plates. All plates were incubated at $37^{\circ} \mathrm{C}$ for 48 hours and after this period the number of colonies in each plate was counted. The Wilcoxon test revealed statistically significant differences $(p=0.002)$ between the results before and after establishment of the proposed infection control protocol. It was concluded that the present protocol reduced the number of microorganisms on the analyzed surfaces and processing solutions.
\end{abstract}

\section{KEYWORDS}

Bacteria, focal infection dental, microbiology, dental radiography.

\section{INTRODUCTION}

The dental office is an environment exposed to risk of infection both for the patient and the professional ${ }^{1,8,9,11}$, thus the employment of barriers is required with a view to reduce the occurrence of infecto-contagious diseases by means of interruption of the "infection chain", therefore avoiding transmission of diseases of different etiologies such as hepatitis B, C and D, herpes simplex and AIDS from patient to professional, from professional to patient or even from patient to patient. Besides the infecto-contagious diseases caused by viruses, bacteria such as staphylococci, pneumococci, mycobacteria, chlamydia, spirochetes and pseudomonas may also infect dental professionals 
and their patients ${ }^{4,5}$. Thus, there is a need to discuss and highlight the importance of such protective barriers both for the professional and staff and for the patient ${ }^{1,6,7,8,12,17}$.

The development of infectious diseases occurs because of a lack of balance between the capacity of immunological defense of the host and the virulence of the pathogenic microorganism ${ }^{10}$.

At the dental office, infections may be transmitted by direct (blood, saliva and other secretions) or indirect contact, by means of saliva drips and contaminated aerosols ${ }^{16}$.

According to Carvalho \& Papaiz ${ }^{4}$ (1999), all material handled during the radiographic examination may act as a means of transmission of pathogens.

Bachman et al. ${ }^{2}$ (1990) observed the presence of microorganisms on the processing solutions and on the surfaces of the darkroom where purposely contaminated radiographic films were handled. They concluded that, despite of the reduction in the number of bacterial colonies on the film surfaces, the potential of cross contamination is maintained.

The current principles of biosecurity aim at avoiding the establishment of the "infection chain", thus the professional must make use of the personal protective equipment (PPE): caps, masks, eye protectors, gowns and gloves during the entire session $^{1,8,11,13}$. Special care should also be provided to the environment, such as disinfection of surfaces between sessions with an alcoholic chlorhexidine solution $^{9,10,18}$. According to the American Academy of Oral and Maxillofacial Radiology ${ }^{1}$ (1992), surfaces that cannot be easily disinfected should be protected by means of a mechanical barrier (PVC film, for example) $)^{1,5,6,8,15,16,18}$.

The aim of this study was to verify the efficiency of a new infection control protocol suggested by the authors, for application in the Radiology Clinic of Sao Paulo State University "Julio de Mesquita Filho", Dental School of Sao Jose dos Campos, UNESP - SP - Brazil, by means of counting of microorganisms on the processing solutions and contact surfaces during accomplishment of intraoral radiographs.

It should be highlighted that biosecurity measures were already employed at the radiology clinic, however new items were added to the other procedures existing, with establishment of a new and more complete protocol when compared to the previous.

\section{Material AND methods}

Samples were collected from different sites at the Radiology Clinic of Sao Paulo State University "Julio de Mesquita Filho", Dental School of Sao Jose dos Campos, UNESP - SP - Brazil, after routine care, before and after application of the new infection control protocol. The laboratory stage was conducted in the microbiology laboratory of the same institution.

Before the establishment of the new protocol, some procedures of biosecurity were employed at the radiology clinic, such as utilization of disposable gloves, washing of hands before and after wearing gloves, avoiding to touch the walls and equipments with contaminated gloves, washing of film holders and bite pads with water and liquid soap, and disposal of all material employed in a proper place. At the darkroom, handle of the film with clean gloves. However, after a literature review, the need was noticed to make use of more protective measures, in order to avoid cross infection during the routine treatment at the Radiology Clinic. For that purpose, the new infection control protocol in Radiology was adopted by the professionals and students (both undergraduate and graduate) of the discipline of Radiology of the mentioned school. Following, the procedures of the new protocol will be described.

Infection Control Protocol in Dental Radiology

Procedures during the session: Washing of hands before and after wearing gloves, wear of disposable gloves in all stages, use of overgloves during achievement of the radiograph and employment of personal protective equipment (disposable masks, gloves and caps, gowns and eye protectors).

Procedures related to the equipments and environment: Avoiding to touch the walls and equipments with contaminated gloves; disinfection of instruments and equipments with alcoholic chlorhexidine solution (70\% ethyl alcohol with 5\% chlorhexidine), by means of the spray-wipe-spray technique (SILVA \& JORGE ${ }^{14}, 2002$ ); sterilization of the film holders and bite pads in autoclave or in $2 \%$ glutaraldehyde solution for ten hours; employment of plastic barriers on the X-ray machines (tube head and buttons), films and dental chair arm rests; enfolding of the surfaces with disposable material (paper or PVC film); disposing of the films in disposable plastic cups after film exposure; dispo- 
sing of all material that will not be used again in a proper place.

Care during processing and on the darkroom: Covering of the working surface (bench) with disposable material, removal of the films from the cups and placement on the previously protected bench, prevention of contamination of the film cover when taking it out of the outer wrapping, removal of the overgloves at the darkroom, handling the film with clean gloves when placing them in the processing tanks or in the automatic processor.

Selection of sites and material collection: The areas employed for data collection were based on the protocol, with selection of the following sites: 1) at the clinic - X-ray tube head, dental chair (arm rest), lead apron (several areas), X-ray buttons and protective barrier (several areas); 2) at the darkroom - bench (area of handling of the films); 3) on the processing solutions - developer solution, water and fixer solution; and 4) on the film. Ten samples were collected from each site, for ten nonconsecutive days, with employment of 140 Replicate Organism Direct Agar Contact surface plates (RODAC, Politec, Brazil) and 60 Petri plates, being half before and half after establishment of the protocol, each one containing blood agar as the culture medium. The RODAC and Petri plates were employed in order to verify the presence of bacteria on the surfaces of the radiology clinic and processing solutions, respectively.

It should be noticed that, after establishment of the new protocol, the staff (technicians and auxiliary personnel) and undergraduate students were not informed on the days selected for accomplishment of the study, in order to avoid possible changes in behavior and therefore alteration in the outcomes.

The disposable sterile RODAC and Petri surface plates were prepared on the microbiology laboratory of Sao Paulo State University "Julio de Mesquita Filho", Dental School of Sao Jose dos Campos, UNESP - SP - Brazil. Afterwards, the RODAC plates were exposed and placed on the selected sites of the radiology clinic for one minute, for ten nonconsecutive days.

On the same period, $5 \mathrm{ml}$ of each processing solution (developer, water and fixer) were also collected by means of sterilized graduated pipettes, adding up to 30 plates. At the darkroom, the contents of the pipettes were placed on sterilized test tubes and $0.1 \mathrm{ml}$ of this content was placed in pre- viously prepared Petri plates with blood agar as the culture medium. All procedure was conducted under asepsis with laminar flow.

Material collection was accomplished before and after employment of the suggested protocol for cross infection control. All material collected was incubated in an oven (Fanem, Franz Sturm S.A., Sao Paulo, Brazil) for forty-eight hours at $37^{\circ} \mathrm{C}$. This was followed by counting of the colony forming units on a counter (CP 600 Plus, Phoenix). The results were expressed in colony forming units per plate (cfu/plate) or per $\mathrm{ml}(\mathrm{cfu} / \mathrm{ml})$.

\section{Results}

After accomplishment of material collection on the selected sites of the radiology clinic and darkroom for ten nonconsecutive days, counting of the number of colonies (cfu/plate) before and after establishment of the new protocol was conducted, and the results are demonstrated in Tables 1 and 2, respectively. During the same period, the processing solutions were collected and the counting of the number of colonies $(\mathrm{cfu} / \mathrm{ml})$ before and after employment of the protocol is demonstrated in Tables 3 and 4, respectively. The influence of the new infection control protocol on the number of bacterial colonies formed on the Petri and RODAC plates can be observed in Figure 1.

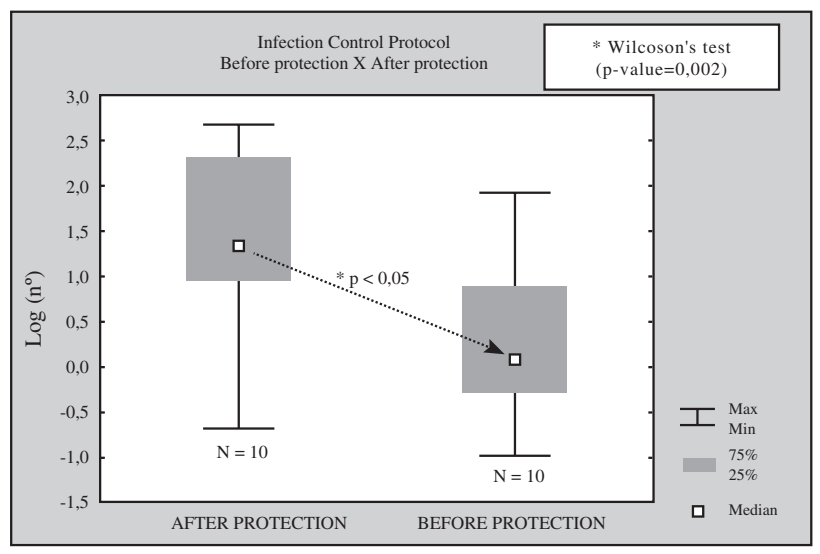

FIGURE 1 - Influence of the new infection control protocol on the number of bacterial colonies, Log (n.), formed on the Petri and RODAC plates. 
Silva MAS, Martins MV, Medici Filho E, Moraes LC, Castilho JCM, Jorge AOC

EVALUATION OF THE EFFICIENCY OF AN INFECTION CONTROL PROTOCOL IN DENTAL RADIOLOGY BY MEANS OF MICROBIOLOGICAL ANALYSIS

Table 1 - Number of colonies (cfu/plate) for each selected site in ten nonconsecutive days, before establishment of the new protocol, at the radiology clinic and the darkroom

\begin{tabular}{cccccccccccc}
\hline & \multicolumn{10}{c}{ Days } \\
\hline Collection Areas & $1^{\circ}$ & $2^{\circ}$ & $3^{\circ}$ & $4^{\circ}$ & $5^{\circ}$ & $6^{\circ}$ & $7^{\circ}$ & $8^{\circ}$ & $9^{\circ}$ & $10^{\circ}$ & Total \\
Film & 74 & 224 & 288 & 904 & 728 & 364 & 104 & 236 & 484 & 724 & 4130 \\
Tube Head & 72 & 1 & 1 & 2 & 10 & 21 & 0 & 1 & 1 & 1 & 110 \\
Dental Chair & 183 & 110 & 16 & 23 & 6 & 4 & 17 & 1 & 28 & 8 & 396 \\
Lead Apron & 4 & 2 & 2 & 13 & 7 & 4 & 17 & 1 & 28 & 8 & 8 \\
Buttons & 556 & 0 & 1372 & 01 & 63 & 1 & 2 & 2 & 1 & 1 & 1999 \\
Protective Barrier & 1 & 3 & 87 & 03 & 4 & 1 & 0 & 0 & 15 & 1 & 115 \\
Darkroom Bench & 115 & 6 & 1 & 46 & 0 & 1 & 283 & 1 & 130 & 127 & 710 \\
\hline Total & 1005 & 346 & 1767 & 992 & 818 & 396 & 423 & 242 & 687 & 870 & 7546 \\
\hline
\end{tabular}

Table 2 - Number of colonies (cfu/plate) for each selected site in ten nonconsecutive days, after establishment of the new protocol, at the radiology clinic and the darkroom

\begin{tabular}{|c|c|c|c|c|c|c|c|c|c|c|c|}
\hline \multicolumn{12}{|c|}{ Days } \\
\hline Collection Areas & $1^{\circ}$ & $2^{\circ}$ & $3^{\circ}$ & $4^{\circ}$ & $5^{\circ}$ & $6^{\circ}$ & $7^{\circ}$ & $8^{\circ}$ & $9^{\circ}$ & $10^{\circ}$ & Total \\
\hline Film & 0 & 29 & 144 & 65 & 62 & 304 & 18 & 80 & 38 & 68 & 808 \\
\hline Tube Head & 5 & 0 & 0 & 0 & 0 & 0 & 0 & 0 & 0 & 0 & 5 \\
\hline Dental Chair & 0 & 0 & 0 & 23 & 1 & 1 & 5 & 47 & 3 & 83 & 163 \\
\hline Lead Apron & 0 & 0 & 0 & 0 & 0 & 0 & 0 & 21 & 1 & 139 & 161 \\
\hline Buttons & 0 & 0 & 13 & 4 & 1 & 7 & 3 & 11 & 1 & 36 & 76 \\
\hline Protective Barrier & 0 & 0 & 0 & 0 & 1 & 1 & 10 & 1 & 0 & 1 & 14 \\
\hline Darkroom Bench & 1 & 4 & 2 & 0 & 0 & 0 & 0 & 0 & 0 & 0 & 7 \\
\hline Total & 6 & 33 & 159 & 92 & 65 & 313 & 36 & 160 & 43 & 327 & 1234 \\
\hline
\end{tabular}


Silva MAS, Martins MV, Medici Filho E, Moraes LC, Castilho JCM, Jorge AOC

EVALUATION OF THE EFFICIENCY OF AN INFECTION CONTROL PROTOCOL IN DENTAL RADIOLOGY BY MEANS OF MICROBIOLOGICAL ANALYSIS

Table 3 - Number of colonies (cfu/plate) for each selected site in ten nonconsecutive days, before establishment of the suggested protocol, on the processing solutions

\begin{tabular}{cccccccccccc}
\hline \multicolumn{10}{c}{ Days } \\
\hline Developing Solutions & $1^{\circ}$ & $2^{\circ}$ & $3^{\circ}$ & $4^{\circ}$ & $5^{\circ}$ & $6^{\circ}$ & $7^{\circ}$ & $8^{\circ}$ & $9^{\circ}$ & $10^{\circ}$ & Total \\
Developer & 400 & 0 & 0 & 0 & 0 & 0 & 0 & 0 & 0 & 120 & 520 \\
Water & 752 & 101 & 12 & 1 & 6 & 24 & 61 & 1604 & 32 & 5 & 2598 \\
Fixer & 1 & 0 & 0 & 0 & 0 & 1 & 0 & 0 & 0 & 1 & 3 \\
\hline Total & 1153 & 101 & 12 & 1 & 6 & 25 & 61 & 1604 & 32 & 126 & 3121 \\
\hline
\end{tabular}

Table 4 - Number of colonies (cfu/plate) for each selected site in ten nonconsecutive days, after establishment of the suggested protocol, on the processing solutions

\begin{tabular}{cccccccccccc}
\hline & \multicolumn{10}{c}{ Days } \\
\hline Developing Solutions & $1^{\circ}$ & $2^{\circ}$ & $3^{\circ}$ & $4^{\circ}$ & $5^{\circ}$ & $6^{\circ}$ & $7^{\circ}$ & $8^{\circ}$ & $9^{\circ}$ & $10^{\circ}$ & Total \\
Developer & 0 & 0 & 0 & 0 & 0 & 0 & 0 & 0 & 0 & 10 & 10 \\
Water & 1 & 0 & 0 & 0 & 0 & 0 & 0 & 0 & 0 & 0 & 1 \\
Fixer & 0 & 0 & 0 & 0 & 0 & 0 & 0 & 0 & 0 & 1 & 1 \\
\hline Total & 1 & 0 & 0 & 0 & 0 & 0 & 0 & 0 & 0 & 11 & 12 \\
\hline
\end{tabular}

\section{Discussion}

Identifying patients with infectious diseases by means of the clinical history, physical examination or laboratory tests is not always possible, consequently infection control should be universally practiced for all patients ${ }^{1,8,16}$. On this basis, a new infection control protocol was applied on the Radiology Clinic of Sao Paulo State University "Julio de Mesquita Filho", Dental School of Sao Jose dos Campos, UNESP - SP - Brazil, with a view to avoid or reduce the transmission of pathogenic microorganisms between patients, dental practitioners, technicians, auxiliary personnel and undergraduate students. Cutting or perforating instruments are not employed for accomplishment of the intraoral radiographic techniques, therefore avoiding contact between the professional and the patient's blood. However, upon introduction of the film on the oral cavity there will be contact with saliva, which may contain several pathogenic microorganisms that can cause different types of infection. Thus, the employment of barriers to avoid or reduce the formation of an infection chain is required.

On the present study, it was observed that, before employment of the suggested protocol, there was contamination of the collection sites at the radiology clinic and processing solutions, which was demonstrated by the presence of a great number of bacterial colonies on the RODAC $(7,546 \mathrm{cfu} / \mathrm{pla}-$ te) and Petri plates $(3,121 \mathrm{cfu} / \mathrm{mL})^{1,2,5,8,9,10}$. These results revealed that the processing solutions exhibited less contamination when compared to the surfaces of the radiology clinic $^{2,3,6,19}$.

After establishment of the new infection control protocol in dental radiology and after achievement of intraoral radiographs, samples were once again collected from the surfaces of the radiology 
clinic and processing solutions, for ten nonconsecutive days, in order to evaluate its efficacy. Statistical analysis of the outcomes achieved revealed a statistically significant reduction $(\mathrm{p}=0.002)$ on the number of bacterial colonies on the surfaces of the radiology clinic $(1,234 \mathrm{cfu} / \text { plate })^{5,9,10,13,15,17,19}$, except for the lead apron, since this surface presented an increase in the number of colonies on the eighth and tenth days, even after strict application of the suggested protocol. This finding led to the conclusion that there may have been negligence concerning the disinfection methods foreseen on the protocol on these days.

As to the processing solutions, a reduction was noticed on the number of bacterial colonies $(12 \mathrm{cfu} /$ $\mathrm{ml}$ ) after employment of the new protocol in all solutions analyzed ${ }^{3,6,18}$.

Since potentially infected subjects are not always identified through the information of their clinical history, physical and clinical examinations and laboratory tests, the adoption of protective measures with a view to avoid or reduce the transmission of pathogenic microorganisms that may cause several types of infecto-contagious diseases is necessary. Thus, it can be assumed that the dentist is the main person in charge of the cross infection control on the working environment and should maintain the asepsis during the accomplishment of radiographic techniques and film processing, as well as to verify whether the measures required for an effective and safe infection control are being followed by all members of the staff. Therefore, the professional should adopt and employ methods of sterilization, disinfection, mechanical barriers and personal protective equipment in all dental specialties, including Radiology, with a view to assure a favorable environment to health maintenance for both staff and patients.

\section{Conclusions}

Through analysis of the outcomes achieved on the present study, the following can be concluded:

1. The protocol suggested by the authors provided a larger reduction in the number of bacterial colonies when compared to the infection control procedures previously employed.

\section{Acknowledgments}

To the professors of the Discipline of Radiology, for their constant overseeing and support provided during the accomplishment of the present study.

To the Chairman Professor Antonio Olavo Cardoso Jorge, for the fundamental support concerning the principles of Microbiology.

To the Technician Clelia Aparecida de Paiva Martins, for the effective participation and supervision during accomplishment of the laboratory procedures.

To the Associate Professor Ivan Balducci, for the valuable statistical analysis.

\begin{abstract}
Resumo
O objetivo deste estudo foi verificar a eficácia de um protocolo para controle de infecção cruzada em radiologia odontológica, durante as fases de técnica e processamento radiográfico, visto que a transmissão de doenças infecciosas deve ser uma preocupação do cirurgião-dentista em todos os procedimentos. As áreas selecionadas para coleta de material foram: filme radiográfico, cabeçote de raios-X, cadeira odontológica, avental de chumbo, interruptor, parede do biombo de chumbo, bancada da câmara escura e as soluções processadoras (revelador, água e fixador). Em cada área, o material foi coletado antes e após a instituição do protocolo. Para cada local escolhido foram utilizadas 10 placas Rodac, perfazendo um total de 140 placas ( 70 antes e 70 após) e 60 placas de Petri (30 antes e 30 após), ambas contendo meio de cultura ágar sangue. As soluções de processamento foram dispensadas nas placas de Petri, enquanto o material obtido, nas demais áreas foi coletado diretamente nas placas Rodac. Em seguida, as placas foram incubadas a $37^{\circ} \mathrm{C}$ durante quarenta e oito horas, para posterior contagem do número de colônias. Os resultados obtidos, quando submetidos ao teste estatístico de Wilcoxon, revelaram diferença significante $(\mathrm{p}=0,002)$ entre a contagem realizada antes e após a utilização do protocolo proposto. Concluiu-se que após a instituição deste protocolo houve redução do número microrganismo nas superfícies examinadas e soluções processadoras.
\end{abstract}

\title{
UNITERMOS
}

Bactérias, infecção focal dentária, controle; microbiologia, radiografia dentária 
Silva MAS, Martins MV, Medici Filho E, Moraes LC, Castilho JCM, Jorge AOC

EVALUATION OF THE EFFICIENCY OF AN INFECTION CONTROL PROTOCOL IN DENTAL RADIOLOGY BY MEANS OF MICROBIOLOGICAL ANALYSIS

\section{References}

1. American Academy of Oral and Maxillofacial Radiology. Infection control guidelines for dental radiographic procedures. Oral Surg Oral Med Oral Pathol 1992 Feb;73(2):248-9.

2. Bachman CE, White JM, Goodis HE, Rosenquist JW. Bacterial adherence and contamination during radiographic processing. Oral Surg Oral Med Oral Pathol 1990 Nov;70(5):669-73.

3. Bajuscak RE, Hall EH, Giambarresi LI, Weaver T. Bacterial contamination of dental radiographic film. Oral Surg Oral Med Oral Pathol 1993:Nov;76(5):661-3.

4. Carvalho PL, Papaiz EG. Controle de infecção em radiologia odontológica. Rev Assoc Paul Cir Dent 1999 maio/jun. ;53(3):202-

5. Hubar JS, Oeschger MP, Reiter LT. Effectiveness of radiographic film barrier envelopes. Gen Dent 1994 Sept/Oct;42(5):406-8.

6. Langland OE, Langlais RP. Procedimentos de controle de infecção radiológica. In: Langland, OE, Langlais, RP. Princípios do diagnóstico por imagem em odontologia. São Paulo : Santos;2002. p.69-84

7. Miller CH. Infection control. Dent Clin North Am 1996 Apr;40(2):437-56

8. Ministério da Saúde Secretaria de Políticas de Saúde. Coordenação Nacional de DST e AIDS. Controle de infecção e a prática odontológica em tempos de Aids 2000:1-45.

9. Molinari JA. Practical infection control for the 1990s:applying science to government regulations. J Am Dent Assoc 1994 Sept;125(9):1189-97.
10. Molinari JA. Dental infection control at the year 2000. Accomplishment recognized. Dent Assist 2000 May-June;69(3):2630,32,34 passim. Review.

11. Neaverth EJ, Pantera EA Jr. Chairside disinfection of radiographs. Oral Surg Oral Med Oral Pathol 1991 Jan;71(1):116.

12. Parks ET, Farman, AG Infection control for dental radiographic procedures in US dental hygiene programmes. Dentomaxillofac Radiol 1992 Feb;21(1):16-20.

13. Puttaiah R, Langlais RP, Katz, JO, Langland OE. Infection control in dental radiology. W V Dent J 1995 May;69(3):15-20.

14. Silva CRG, Jorge AOC. Avaliação de desinfetantes de superfície utilizados em odontologia. Pesqui Odontol Bras 2002 abr./ jun.;16(2):107-14.

15. Stanczyk DA, Paunovich ED, Broome JC, Fatone MA. Microbiologic contamination during dental radiographic film processing. Oral Surg Oral Med Oral Pathol 1993 July;76(1):112-9.

16. Terezhalmy GT, Gitto CA. Today's minimal requirements for a practical dental office infection control and exposura control program. Dent Clin North Am 1998 Oct;42(4):629-42.

17. Tullner JB, Zeller G, Hartwell GA, Burton J. A practical barrier technique for infection control in dental radiology. Compend Contin Educ Dent 1992 Nov;13(11):1054-56.

18. White SC, Glaze S. Interpatient microbiological cross-contamination after dental radiographic examination. J Am Dent Assoc 1978 May;96(5):801-4.

19. Wolfgang L. Analysis of a new barrier infection control system for dental radiographic film. Compend Contin Educ Dent 1992 Jan;13(1):68-71

Recebido em: 07/08/03 Aprovado em: 03/11/03

Faculdade de Odontologia de São José dos Campos - Unesp Departamento de Cirurgia, Periodontia e Radiologia Av. Eng. Francisco José Longo, 777 - Caixa Postal 314 Cep. 12245-000 - Jardim São Dimas São José dos Campos - SP - Brasil Tel: (12) 39479054 e-mail: denteok@bol.com.br 